\title{
The Use of Microbial Biotechnology in Value Addition to Cassava Wastes as Feed for Pigs: Prospects and Challenges
}

\author{
Samuel Olanrewaju Aro ${ }^{*}$, Andrew Bamidele Falowo², Olusola Olufisayo Awoneye ${ }^{3}$, \\ Valentine Ayobare Aletor ${ }^{1}$ \\ ${ }^{1}$ Department of Animal Production and Health, The Federal University of Technology, Akure, Nigeria \\ ${ }^{2}$ Department of Livestock and Pasture Science, University of Fort Hare, Alice, South Africa \\ ${ }^{3}$ Department of Animal Production, Rufus Giwa Polytechnic, Owo, Nigeria \\ Email: sambolaro@yahoo.co.uk
}

Received 5 January 2015; accepted 22 January 2015; published 23 January 2015

Copyright (C 2015 by authors and Scientific Research Publishing Inc.

This work is licensed under the Creative Commons Attribution International License (CC BY). http://creativecommons.org/licenses/by/4.0/

(c) (i) Open Access

\section{Abstract}

Cassava peels were fermented through a combination of two lactic acid bacteria (Lactobacillus coryneformis and Lactobacillus delbrueckii) and a fungus (Aspergillus fumigatus) using solid substrate fermentation (SSF) technique for five consecutive days. The enhanced product designated as microbially fermented cassava peel (MFCP) was used at graded levels in the feed formulation for growing pigs. Four iso-nitrogenous and iso-caloric diets were formulated with MFCP at 0\% (T1), $20 \%$ (T2), $40 \%$ (T3) and $60 \%$ (T4) inclusion levels. Twenty-four boarlings of an average initial weight of $37.15 \mathrm{~kg}$ were used in a fourteen-week trial to test the effect of these graded levels of MFCP on growth performance, digestive and reproductive physiology of the experimental animals. The result showed significant differences $(P<0.05)$ in mean daily feed consumption. Pigs in T3 had the highest feed intake $(2.24 \pm 0.05 \mathrm{~kg})$, while pigs in $\mathrm{T} 4 \mathrm{had}$ the lowest $(1.78 \pm 0.04 \mathrm{~kg})$. The final highest live weight was in $T 3(72.00 \mathrm{~kg})$ and the least in $\mathrm{T} 4(58.17 \mathrm{~kg})$. The feed conversion ratios also showed significant differences $(P<0.05)$ among treatment means. The result obtained from gut morphometry showed that animals in T1 had the highest stomach weight (full and empty), while animals in T3 had the least rate of gastric emptying (81.50\%). Animals in T3 and T4 had the longest small intestine (16.21 $\mathrm{m}$ and $15.35 \mathrm{~m}$, respectively), while those in T4 had the longest colon (4.24 m). Animals in T1 and T2 had more numbers of gastric glands, while animals in T3 and T4 had more parietal cells. The reproductive indices revealed that animals in $\mathrm{T} 1$ were better in terms of the weight and relative weight of vesicular and Cowper's gland, while animals in T4 had the highest value of the weight and relative weight of prostate gland. Proximate analyses of the ileal digesta revealed that the rate of nutrient absorption was highest in $\mathrm{T} 3$ and $\mathrm{T} 1$ and lowest in T4. Histological examination of the testes revealed normal testicular architecture in the control

\footnotetext{
"Corresponding author.
} 
diet. The testes of animals fed $0 \%, 20 \%$ and $40 \%$ MFCP diets exhibited normal and intact lumen, Sertoli cells, and germ cells. However, animal fed $60 \%$ MFCP diet revealed massive disruption and degeneration of germinal epithelium, and complete erosion of the seminiferous tubules. It could be concluded that feeding pigs at $40 \%$ MFCP would enhance feed consumption, nutrient absorption and improve the growth rate of pigs. Using MFCP beyond $40 \%$ level on swine diet could compromise gut health through diarrhoeagenic disposition of the digesta in the distal colon and modification of the parietal and chief cells of the gastric glands. The hypertrophy of the prostate gland and vacuolization of the seminiferous tubules of pigs fed the $60 \%$ MFCP diet indicated a probable reduced reproductive performance.

\section{Keywords}

\section{Biotechnology, Cassava, Fermentation, Microbes, Physiology}

\section{Introduction}

Globally, livestock production is growing more dynamically than any other agricultural sector. As countries become more affluent, demand for livestock-derived food has substantially increased, leading to a major transformation of animal food production. Pig and poultry production are the fastest growing and industrialized livestock subsectors with annual production growth rates of $2.6 \%$ and $3.7 \%$ respectively over the past decade [1]. Sources of animal protein in Nigeria include beef, milk, pork, poultry, sheep, goats, fish and game animals. Of all the sources, pork represents one of the fastest ways of increasing animal protein, since pigs grow at a faster rate and are more prolific than cattle, sheep and goats [2]. Also pigs excel other animals in converting feed to flesh [3] and they display a unique ability to adapt and survive in areas where they have been found. However, the development of the swine industry has been plagued by the increasing unavailability and consequent high cost of the conventional feeds. Feed cost, according to Sastry and Thomas [4], accounts for $67.2 \%$ of the total pig production cost. It is therefore pertinent to look for cheaper and readily available sources for compounding swine rations. As a way of confronting this challenge, the use of alternative feed sources such as cassava peel and cassava starch residue has been canvassed [5].

The potential use of cassava peel to adequately fill this nutritional gap is heavily constrained by intrinsic factors like their high crude fibre level, low nitrogen content and the presence of anti-nutrients [6]. There has been a concerted effort by scientists to reduce or totally remove all these constraints militating against the utilization of cassava peels. The most viable option for circumventing these constraints is via the biotechnological route using generally regarded as safe (GRAS) organisms [7]. A host of micro-organisms which can be used for value addition to agro-industrial by-products abound and have been used by researchers with varying degrees of success. Thus, this research was designed to investigate the effect of using graded levels of cassava peel fermented with a combination of two lactic acid bacteria (Lactobacillus coryneformis and Lactobacillus delbrueckii) and a fungus (Aspergillus fumigatus) on the growth performance, gut and gonadal morphometry of growing pigs.

\section{Materials and Methods}

Fresh cassava peels were collected from cassava processing mills within Akure town, Ondo State, Nigeria. The peels were processed by the methods described by Aro [5] prior to their incorporation into the compounded grower pigs' diets. A total of 24 grower pigs (all males) with average initial weight of $37.15 \mathrm{~kg}$ were purchased for the trial. Four experimental diets were formulated to contain microbially fermented cassava peel (MFCP) at $0 \%, 20 \%, 40 \%$ and $60 \%$ as diet 1 , diet 2 , diet 3 and diet 4 respectively. The diets composition is shown in Table 1. The animals were randomly divided into four treatments, comprising of six animals per treatment with each animal serving as a replicate of its treatment group.

Data were collected for weekly weight change, daily feed intake and feed conversion ratio throughout the 14 weeks of the trial. At the end of the experiment, all the animals were mechanically stunned and slaughtered. Immediately after death, the abdominal cavity was opened and the entire gastrointestinal tract was immediately removed. Different sections of the gastro-intestinal tract were ligated and cut into the following segments: sto- 
Table 1. Gross composition $(\mathrm{g} / 100 \mathrm{~g})$ of the experimental diets.

\begin{tabular}{ccccc}
\hline Ingredients & T1 & T2 & T3 & T4 \\
\hline Maize & 40.00 & 35.00 & 15.00 & 0.00 \\
Rice bran & 11.00 & 7.20 & 10.00 & 0.00 \\
Palm kernel cake & 26.30 & 16.50 & 14.50 & 21.30 \\
Groundnut cake & 17.00 & 18.30 & 17.50 & 15.70 \\
MFCP & -------- & 20.00 & 40.00 & 60.00 \\
Vegetable oil & 2.50 & -------- & ------- & ------- \\
Bone meal & 1.50 & 1.50 & 1.50 & 1.50 \\
Oyster shell & 0.50 & 0.50 & 0.50 & 0.50 \\
Premix & 0.50 & 0.50 & 0.50 & 0.50 \\
Salt & 0.50 & 0.50 & 0.50 & 0.50 \\
Total & 100.00 & 100.00 & 100.00 & 100.00 \\
Crude protein $(\%)$ & 18.07 & 18.09 & 18.09 & 18.04 \\
Crude fibre (\%) & 6.20 & 11.35 & 17.87 & 24.01 \\
M. E. (Kcal/kg) & 3022.82 & 3012.30 & 3003.15 & 3015.74 \\
HCN Conc. (mg/kg) & 0.00 & 5.88 & 11.16 & 16.75 \\
\hline
\end{tabular}

MFCP $=$ Microbially fermented cassava peel; $\mathrm{HCN}=$ Hydrogen cyanide; $\mathrm{M}$. E. $=$ Metabolizable energy; T1 = Control diet; T2 = Diet with $20 \%$ inclusion of MFCP; T3 = Diet with $40 \%$ inclusion of MFCP; T4 $=$ Diet with $60 \%$ inclusion of MFCP.

mach, small intestine, large intestine and caecum for measurement. The length of small and large intestine were determined using a linear measuring tape. The weights of caecum and stomach (full and empty) were also determined.

Tissue samples from the stomach and testis were collected for histological examination. Sections were then observed with a light microscope and photographs were taken at $600 \times$ magnification. Also, gonadal parameters like the weight of the accessory glands and testicular histology were determined as response criteria to the treatment diets.

\section{Data Analysis}

Data generated were subjected to analysis of variance (ANOVA) using SPSS version 16 statistical package. Mean separation was done with Duncan's multiple range test of the same statistical package.

\section{Results and Discussion}

The result of the performance of grower pigs fed varying levels of MFCP is shown in Table 2. The average feed intake values differed significantly $(P<0.05)$. The animals on T3 had highest feed intake $(2.24 \pm 0.05 \mathrm{~kg})$, while animals on T4 had the least $(1.78 \pm 0.04 \mathrm{~kg})$. Since the experimental diets were both iso-caloric and iso-nitrogenous, any increase in feed intake represents an increase in the intake of energy and protein requirement [8], which was translated to better protein accretion and hence increased growth rate by the animals on T3. This same trend was reflected on other performance parameters like final body weight feed conversion ratio and daily weight gain. The poor performance recorded for animals on T4 as far as these parameters are concerned could be attributed to high fiber level and the toxigenic effect of residual cyanide at $60 \%$ level of inclusion. The better feed conversion ratio and feed efficiency for animals on the control diet could be attributed to better digestibility as a result of lower level of crude fibre and probable absence of hydrogen cyanide (HCN) on the diet [5]. $\mathrm{HCN}$ intake per body weight was highest in animal on diet T4 and least on diet T2. The lethal dose of HCN for human has been reported to be between $0.5-3.5 \mathrm{mg}$ per kg body weight or 30 and $210 \mathrm{mg}$ for $60 \mathrm{~kg}$ adult human [9]. Since pig is similar to human in body physiology, the high oral intake of HCN per kg body weight $(0.51 \mathrm{mg} / \mathrm{kg})$ 
Table 2. Growth performance of pigs fed microbially fermented cassava peel diet.

\begin{tabular}{ccccc}
\hline Parameters & T1 & T2 & T3 & T4 \\
\hline Average feed intake $(\mathrm{kg} / \mathrm{d})$ & $1.84 \pm 0.56^{\mathrm{b}}$ & $1.94 \pm 0.18^{\mathrm{b}}$ & $2.24 \pm 0.05^{\mathrm{a}}$ & $1.78 \pm 0.04^{\mathrm{b}}$ \\
Initial live weight $(\mathrm{kg})$ & $37.00 \pm 4.49$ & $37.67 \pm 3.23$ & $37.50 \pm 2.03$ & $37.17 \pm 2.17$ \\
Final live weight $(\mathrm{kg})$ & $70.50 \pm 9.27$ & $64.00 \pm 7.21$ & $72.00 \pm 3.76$ & $58.00 \pm 0.89$ \\
Total weight gain $(\mathrm{kg})$ & $33.50 \pm 5.47$ & $26.33 \pm 4.26$ & $34.50 \pm 5.22$ & $20.83 \pm 2.14$ \\
Daily weight gain $(\mathrm{kg})$ & $0.34 \pm 0.06$ & $0.27 \pm 0.04$ & $0.35 \pm 0.06$ & $0.21 \pm 0.02$ \\
FCR & $5.41 \pm 1.40^{\mathrm{b}}$ & $7.19 \pm 1.62^{\mathrm{b}}$ & $6.40 \pm 1.75^{\mathrm{b}}$ & $8.48 \pm 0.80^{\mathrm{a}}$ \\
Feed efficiency & $0.19 \pm 0.03^{\mathrm{a}}$ & $0.14 \pm 0.04^{\mathrm{a}}$ & $0.16 \pm 0.02^{\mathrm{a}}$ & $0.12 \pm 0.01^{\mathrm{b}}$ \\
HCN intake/kg body weight $(\mathrm{mg} / \mathrm{kg})$ & $0.00 \pm 0.00^{\mathrm{d}}$ & $0.18 \pm 0.24^{\mathrm{c}}$ & $0.35 \pm 0.16^{\mathrm{b}}$ & $0.51 \pm 0.07^{\mathrm{a}}$ \\
\hline
\end{tabular}

Mean \pm Standard Deviation. ${ }^{\mathrm{a}, \mathrm{b}, \mathrm{c}, \mathrm{d}}=$ Means with different superscripts within the same rows and for the same parameters are significantly different $(P<0.05)$; MFCP $=$ Microbially fermented cassava peel; $\mathrm{T} 1=0 \% \mathrm{MFCP}$ inclusion as control diet; T2 $=20 \%$ MFCP inclusion of the diet; T3 $=40 \%$ MFCP inclusion of the diet; T4 $=60 \%$ MFCP inclusion of the diet; $\mathrm{FCR}=$ Feed conversion rate $\mathrm{HCN}=$ Hydrogen cyanide

recorded for animals on T4 could have resulted in poor growth of the animals. Hence HCN/kg body weight in MFCP for growers pig should not $0.35 \mathrm{mg} / \mathrm{kg}$ for better growth performance.

The morphometric data (Table 3 ) of the pigs' gastrointestinal tract showed that animals on the control diet (T1) had the highest full stomach weight $(1.42 \pm 0.61 \mathrm{~kg})$ while T4 had the least full stomach weight $(0.88 \pm 0.17 \mathrm{~kg})$.

The weight of stomach content (ingesta) was highest in $\mathrm{T} 3$ than in all other treatments. This probably depicts that animals on $\mathrm{T} 3$ retained dietary nutrients in the stomach for digestion/processing longer than animals on $\mathrm{T} 1$, $\mathrm{T} 2$, and T4. This could also mean that dietary nutrients were retained longer and made more accessible to enzymatic digestion and hence responsible for the presence of more number of parietal cells (Figure 1). The greater accessibility of dietary nutrients to enzymatic digestion may explain why animal on T3 had longest small intestine $(16.21 \pm 0.86 \mathrm{~m})$ and largest caecum $(0.83 \pm 0.17 \mathrm{~kg})$ compared to $\mathrm{T} 1, \mathrm{~T} 2$, and $\mathrm{T} 4$. The caecum was reported to play an important role with respect to the microbial degradation of some carbohydrates [10], absorption of water, microbial synthesis of vitamins and degradation of nitrogenous compounds. Also, the increase in length of the small intestine of pigs on T3 may be to accommodate more ingested nutrients for processing and absorption since small intestine has been reported as the site for nutrient absorption [11].

Histological examination of the fundic region of the stomach (Figure 1) revealed gastric glands comprising mainly of parietal (oxyntic) cells and chief (zymogenic) cells, gastric pit and gastric lumen (Figure 1). The result showed that animals fed T1 and T2 had more number of gastric glands than animals fed T3 and T4. The number of gastric glands in animals fed T1 was similar to those fed T2. This shows that the probable toxigenic effect of residual cyanide did not cause major upset at $20 \%$ inclusion level. The reduction in the number of gastric glands in animal fed T3 and T4 could probably be due to high toxigenic effect of residual cyanide in the diet at $40 \%$ and $60 \%$ inclusion reducing the proliferation of gastric glands for acid secretion.

In animals fed T4, there were alterations in shape and structure of gastric glands with parietal cells unevenly distributed in the glands. The chief cells were not fully formed. The toxigenic nature of residual cyanide at $60 \%$ inclusion may have caused the malformation of chief cells and gastric glands observed in stomach of animals fed T4. Hence most of the nutrients in the diet (T4) must have escaped the stomach without much action of hydrochloric acid secretion for digestion.

The rate of gastric emptying and proximate composition of the ileal content (Table 4) showed that there were significant $(P<0.05)$ treatment effects. T4 had the highest rate of gastric emptying $(88.89 \%)$, followed by T2 $(83.87 \%)$ and the lowest value $(81.02 \%)$ was observed on T1. The high rate of gastric emptying on T4 was contrary to the work of many researchers which revealed that high dietary fibre slows down the rate of gastric emptying [12]. The reason for this disparity may be due to the fact that the fibre on T4 act as emulsifiers by stabilizing the gastric chyme thus preventing the separation of the solid from the liquid phase thereby impairing selective retention of the largest particles and increasing the rate of passage into small intestine thus making the nutrients inaccessible to gastric enzymes for digestion. 
Table 3. Gut Morphometry of grower pigs fed microbially fermented cassava peels diet.

\begin{tabular}{ccccc}
\hline Parameters Weight of Stomach & T1 & T2 & T3 & T4 \\
\hline Full (kg) & $1.42 \pm 0.61$ & $0.92 \pm 0.14$ & $1.20 \pm 0.15$ & $0.88 \pm 0.17$ \\
Empty (kg) & $0.87 \pm 0.37^{\mathrm{a}}$ & $0.43 \pm 0.33^{\mathrm{b}}$ & $0.36 \pm 0.18^{\mathrm{b}}$ & $0.48 \pm 0.06^{\mathrm{b}}$ \\
Weight of stomach content (kg) & $0.55 \pm 0.16^{\mathrm{b}}$ & $0.49 \pm 0.13^{\mathrm{b}}$ & $0.84 \pm 0.22^{\mathrm{a}}$ & $0.40 \pm 0.13^{\mathrm{b}}$ \\
Weight of empty Caecum (kg) & $0.67 \pm 0.07^{\mathrm{ab}}$ & $0.62 \pm 0.04^{\mathrm{b}}$ & $0.83 \pm 0.17^{\mathrm{a}}$ & $0.51 \pm 0.02^{\mathrm{c}}$ \\
Length of small intestine (m) & $15.28 \pm 0.75$ & $14.59 \pm 1.11$ & $16.21 \pm 0.86$ & $15.35 \pm 0.43$ \\
Length of large intestine (m) & $4.11 \pm 0.56$ & $4.53 \pm 0.25$ & $4.22 \pm 0.15$ & $4.24 \pm 0.17$ \\
\hline
\end{tabular}

Mean \pm Standard Error. ${ }^{\mathrm{a}, \mathrm{b}, \mathrm{c}, \mathrm{ab}}=$ Means with different superscripts within the same rows and for the same parameters are significantly different $(P<0.05) ; \mathrm{MFCP}=$ Microbially fermented cassava peel; $\mathrm{T} 1=$ Control diet; $\mathrm{T} 2=$ Diet with $20 \%$ inclusion of MFCP; T3 = Diet with $40 \%$ inclusion of MFCP; T4 $=$ Diet with $60 \%$ inclusion of MFCP.

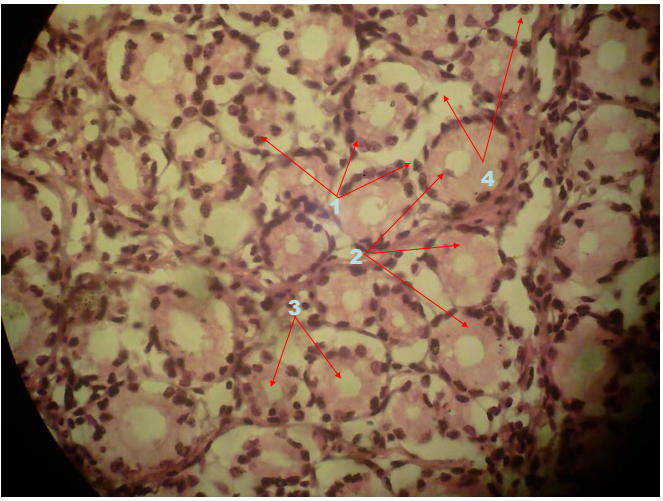

T1

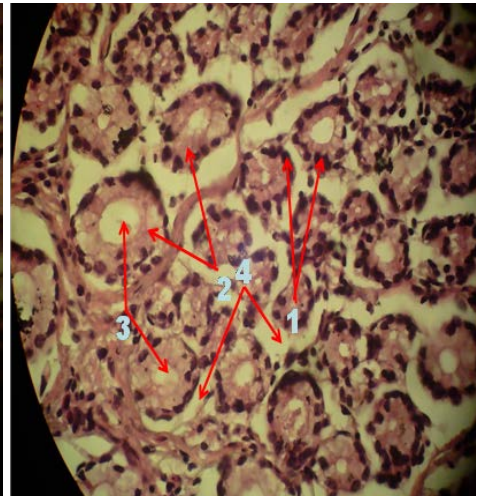

$\mathrm{T} 2$
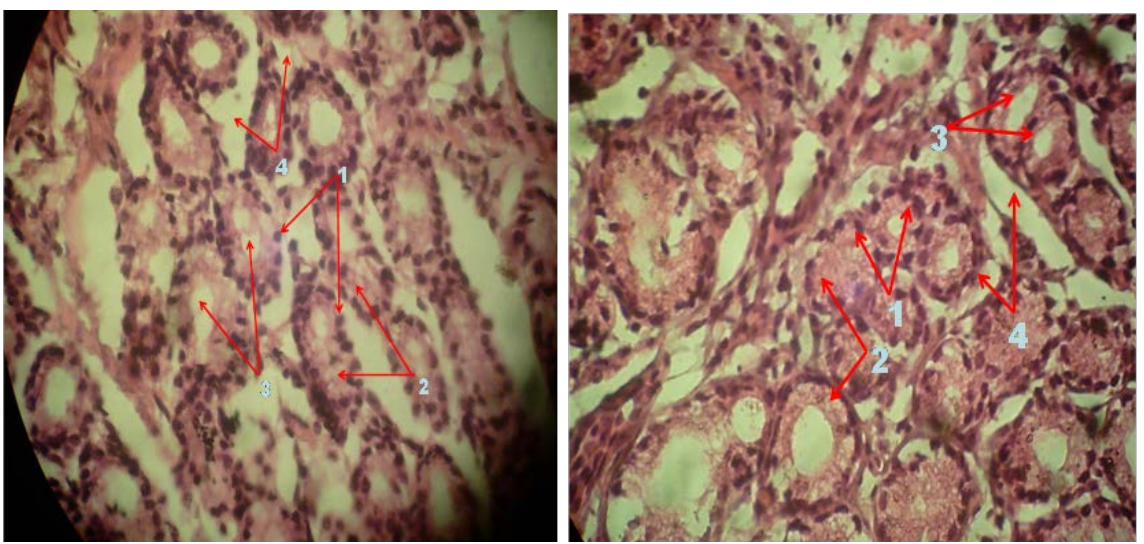

1: Parietal cells; 2: Chief cells; 3: Gastric pit; 4: Gastric lumen. T1: Stomach section of animals fed the control diet; T2: Stomach section of animals fed diet with 20\% MFCP; T3: Stomach section of animals fed diet with $40 \%$ MFCP; T4: Stomach section of animals fed diet with 60\% MFCP. MFCP: Microbially fermented cassava peel. Magnification $600 \times$ (H \& E stains).

Figure 1. Cross sections of Gastric glands from the fundic region of pigs fed microbially fermented cassava peels.

The ileal content of T4 had the lowest dry matter (DM) value $(16.36 \mathrm{~g} / 100 \mathrm{~g})$ while T3 had the highest value $(19.42 \mathrm{~g} / 100 \mathrm{~g})$. Conversely, T4 had the highest moisture content. The high moisture content in T4 may be as a result of the water binding ability of dietary fibre [13]. It also agrees with the report of Varel and Yen [14] that the amount of digesta flow at the terminal ileum is greater in pigs fed diets with high level of dietary fibre. T4 had the highest CP value $(18.33 \mathrm{~g} / 100 \mathrm{~g})$ while the lowest crude protein content of the ileum was recorded in T3 $(13.74 \mathrm{~g} / 100 \mathrm{~g})$. The high crude protein content in T4 is an indication that crude protein was not well absorbed 
Table 4. Proximate composition $(\mathrm{g} / 100 \mathrm{~g})$ of ileal digesta and rate of gastric emptying (\%) of pigs fed graded levels of fermented cassava peel-based diets.

\begin{tabular}{|c|c|c|c|c|}
\hline Parameters & $\mathrm{T} 1$ & $\mathrm{~T} 2$ & $\mathrm{~T} 3$ & $\mathrm{~T} 4$ \\
\hline DM & $19.05 \pm 0.42^{\mathrm{ab}}$ & $17.95 \pm 0.30^{\mathrm{b}}$ & $19.42 \pm 0.42^{\mathrm{a}}$ & $16.36 \pm 0.30^{\mathrm{c}}$ \\
\hline Moisture & $80.95 \pm 0.42^{\mathrm{ab}}$ & $82.05 \pm 0.30^{\mathrm{b}}$ & $80.58 \pm 0.42^{\mathrm{c}}$ & $83.64 \pm 0.30^{\mathrm{a}}$ \\
\hline Crude fibre & $11.20 \pm 0.09^{\mathrm{c}}$ & $13.18 \pm 0.30^{\mathrm{b}}$ & $11.37 \pm 0.04^{\mathrm{c}}$ & $15.64 \pm 0.34^{\mathrm{a}}$ \\
\hline $\mathrm{CP}$ & $15.60 \pm 0.19^{\mathrm{b}}$ & $18.10 \pm 0.35^{\mathrm{ab}}$ & $13.74 \pm 0.39^{\mathrm{c}}$ & $18.33 \pm 0.22^{\mathrm{a}}$ \\
\hline $\mathrm{EE}$ & $9.51 \pm 0.07^{\mathrm{c}}$ & $9.76 \pm 0.06^{\mathrm{b}}$ & $9.70 \pm 0.04^{\mathrm{bc}}$ & $10.31 \pm 0.07^{\mathrm{a}}$ \\
\hline Ash & $11.07 \pm 0.41^{\mathrm{b}}$ & $9.25 \pm 0.13^{c}$ & $10.62 \pm 0.10^{\mathrm{b}}$ & $12.14 \pm 0.34^{\mathrm{a}}$ \\
\hline NFE & $52.63 \pm 0.22^{\mathrm{b}}$ & $49.69 \pm 0.20^{\mathrm{c}}$ & $54.57 \pm 0.35^{\mathrm{a}}$ & $43.57 \pm 0.62^{\mathrm{d}}$ \\
\hline RGE & $81.02 \pm 8.51^{\mathrm{b}}$ & $83.87 \pm 4.35^{\mathrm{b}}$ & $81.50 \pm 6.99^{b}$ & $88.89 \pm 3.67^{\mathrm{a}}$ \\
\hline
\end{tabular}

and this could be as a result of the high crude fibre content of this diet. This is in consonance with the report of Bindelle [15] that an average of $31 \%$ of nitrogen is bound to the fibre and it is not available to the animal, more so, the anti-nutritional factors interfere with the digestive processes. The ileal crude fibre content was generally high in all the treatments, this showed that there was little or no digestion of fibre in the ileum, this could be as a result of the inability of the digestive enzymes of the ileum to digest crude fibre components [16].

The low fat content of $\mathrm{T} 1$ is an indication that fat was well absorbed in T1, while high fat content in T4 is an indication of poor absorption and this may be as a result of the fact that dietary fibre hinders the absorption of all other nutrients [17]. The lowest NFE value of ileal samples was observed in T4 (43.57 g/100 g), while the highest value was observed in T3 $(54.57 \mathrm{~g} / 100 \mathrm{~g})$. The highest NFE recorded in T3 indicates that digestion of soluble carbohydrates was highest as a result of its slow transit or long retention time in the ileum there by enhancing the time of exposure of the diets to the host's digestive enzymes [18].

Table 5 shows the proximate composition of the content of gastro-intestinal tract from the distal colon. T4 had the lowest DM value $(29.36 \mathrm{~g} / 100 \mathrm{~g})$ and the highest moisture content $(70.64 \mathrm{~g} / 100 \mathrm{~g}$ while $\mathrm{T} 1 \mathrm{had}$ the highest DM value of $38.75 \mathrm{~g} / 100 \mathrm{~g}$ the lowest moisture value $(61.25 \mathrm{~g} / 100 \mathrm{~g})$. The high moisture content in T4 is an indication that water was less absorbed and this corroborates the findings of Spiller [19] that dietary fibre has a role in changing the consistency of the stool by increasing the water content and the plasticity thus increasing stool frequency and output, as a result, the high moisture content recorded in T4 is a predisposition to diarrhoeagenic condition [20].

Table 6 shows the accessory sex glands morphometry of the pigs fed microbially fermented cassava peelbased diets. There were significant differences $(P<0.05)$ in the vesicular glands due to treatment effects. The highest weight of vesicular glands $(0.35 \mathrm{~kg})$ was recorded in T1 while T2 had the lowest value $(0.15 \mathrm{~kg})$. The heaviest prostates $(0.15 \mathrm{~kg})$ were recorded in T2 and T4 while T1 had the heaviest Cowper's glands.

Pigs that were fed T1 had the heaviest vesicular glands when compared with pigs fed MFCP diets. The toxigenic effect of the residual cyanide of the cassava peel could have been responsible for the low weight of the vesicular glands in the MFCP-fed pigs. The heavier vesicular glands in pigs that were fed T1 is an indication of greater fluid volume of semen to ensure optimum motility and fertility [21]. T2 and T4 had heavier prostate glands while the lowest was recorded in T3. The general observation was that there is the tendency of bigger prostate glands with pigs fed MFCP-based diets. The abnormal enlargement of the prostate gland has been implicated in prostate cancer that is currently ravaging human population [22].

Table 7 shows that the dietary treatments resulted in a higher relative weight of the vesicular glands and Cowper's glands in the control relative to the MFCP diets. Components of the secretions from the glands are known to ensure nutrition of the sperm cells as well as acting as buffer on the maintenance of the semen's acidbase balance aside from contributing to the electrolyte stability of the seminal plasma. The reduced weight of 
Table 5. Proximate composition $(\mathrm{g} / 100 \mathrm{~g})$ of the digesta from distal colon (dry matter basis) of pigs fed graded levels of fermented cassava peel-based diets.

\begin{tabular}{ccccc}
\hline Parameters & T1 & T2 & T3 & T4 \\
\hline DM & $38.75 \pm 0.42^{\mathrm{a}}$ & $33.37 \pm 0.30^{\mathrm{b}}$ & $37.78 \pm 0.39^{\mathrm{a}}$ & $29.36 \pm 0.41^{\mathrm{c}}$ \\
Moisture & $61.25 \pm 0.42^{\mathrm{c}}$ & $66.63 \pm 0.30^{\mathrm{b}}$ & $62.22 \pm 0.39^{\mathrm{c}}$ & $70.64 \pm 0.41^{\mathrm{a}}$ \\
CF & $8.18 \pm 0.08^{\mathrm{c}}$ & $9.47 \pm 0.09^{\mathrm{b}}$ & $8.45 \pm 0.06^{\mathrm{c}}$ & $12.92 \pm 0.26^{\mathrm{a}}$ \\
CP & $15.18 \pm 0.21^{\mathrm{b}}$ & $16.85 \pm 0.33^{\mathrm{a}}$ & $15.07 \pm 0.27^{\mathrm{b}}$ & $16.97 \pm 0.43^{\mathrm{a}}$ \\
EE & $8.76 \pm 0.07^{\mathrm{bc}}$ & $8.93 \pm 0.08^{\mathrm{b}}$ & $8.31 \pm 0.07^{\mathrm{c}}$ & $10.11 \pm 0.29^{\mathrm{a}}$ \\
Ash & $11.06 \pm 0.37^{\mathrm{bc}}$ & $10.28 \pm 0.15^{\mathrm{c}}$ & $11.46 \pm 0.22^{\mathrm{ab}}$ & $12.28 \pm 0.38^{\mathrm{a}}$ \\
NFE & $56.82 \pm 0.55^{\mathrm{a}}$ & $54.48 \pm 0.26^{\mathrm{b}}$ & $56.71 \pm 0.58^{\mathrm{a}}$ & $47.73 \pm 0.40^{\mathrm{c}}$ \\
\hline
\end{tabular}

a, b, c, ab, bc $=$ Means on the same rows but with different superscripts are statistically $(P<0.05)$ significant; $\mathrm{DM}=$ Dry matter; $\mathrm{CF}=$ Crude fibre; $\mathrm{CP}=$ Crude protein; $\mathrm{EE}=$ Ether extract; NFE = Nitrogen free extract; $\mathrm{T} 1=0 \%$ inclusion of MFCP (Control); $\mathrm{T} 2=20 \%$ inclusion of MFCP; $\mathrm{T} 3=40 \%$ inclusion of MFCP; $44=60 \%$ inclusion of MFCP.

Table 6. Weight of accessory sex gland (kg) of pigs fed graded levels of microbially fermented cassava peel-based diets.

\begin{tabular}{|c|c|c|c|c|}
\hline Parameters & $\mathrm{T} 1$ & $\mathrm{~T} 2$ & $\mathrm{~T} 3$ & $\mathrm{~T} 4$ \\
\hline Vesicular gland & $0.35 \pm 0.03^{\mathrm{a}}$ & $0.15 \pm 0.03^{d}$ & $0.30 \pm 0.11^{b}$ & $0.23 \pm 0.04^{\mathrm{c}}$ \\
\hline Prostate gland & $0.10 \pm 0.00^{\mathrm{b}}$ & $0.15 \pm 0.03^{\mathrm{a}}$ & $0.08 \pm 0.01^{\mathrm{c}}$ & $0.15 \pm 0.06^{\mathrm{a}}$ \\
\hline Cowper's gland & $0.20 \pm 0.00^{\mathrm{a}}$ & $0.13 \pm 0.01^{\mathrm{b}}$ & $0.13 \pm 0.01^{b}$ & $0.13 \pm 0.01^{\mathrm{b}}$ \\
\hline
\end{tabular}

Table 7. Relative weights $(\mathrm{g} / 100 \mathrm{~g})$ of the accessory sex glands of pigs fed graded levels of microbially fermented cassava peel-based diets.

\begin{tabular}{ccccc}
\hline Parameters & T1 & T2 & T3 & T4 \\
\hline Vesicular gland & $0.53 \pm 0.05^{\mathrm{a}}$ & $0.23 \pm 0.02^{\mathrm{c}}$ & $0.44 \pm 0.17^{\mathrm{b}}$ & $0.41 \pm 0.09^{\mathrm{b}}$ \\
Prostate gland & $0.15 \pm 0.01^{\mathrm{b}}$ & $0.25 \pm 0.07^{\mathrm{a}}$ & $0.11 \pm 0.02^{\mathrm{c}}$ & $0.28 \pm 0.11^{\mathrm{a}}$ \\
Cowper's gland & $0.30 \pm 0.02^{\mathrm{a}}$ & $0.20 \pm 0.01^{\mathrm{b}}$ & $0.19 \pm 0.03^{\mathrm{b}}$ & $0.23 \pm 0.03^{\mathrm{b}}$ \\
\hline $\begin{array}{l}\text { a, b, c }=\text { means on the same rows but with different superscripts are statistically }(P<0.05) \text { significant; T1 } \\
=0 \% \text { inclusion of MFCP (control); T2 }=20 \% \text { inclusion of MFCP; T3 }=40 \% \text { inclusion of MFCP; T4 }\end{array}$
\end{tabular}

these two glands in pigs fed MFCP in comparison with those in the control would therefore mean less secretion and hence reduced ovum fertilizing capacity of the seminal plasma of pigs fed MFCP-based diets. The relatively lower weights of the vesicular and Cowper's glands would have been caused by the adverse effect of residual cyanide in the peels [5] [23].

The histopathology of the testes of animals on T1 (control diet) in Figure 2 revealed normal testicular architecture with distinct seminiferous tubule composed of Sertoli cells, germ cells with active stages of spermatogenesis with intact lumen. The interstitial cells of Leydig were also prominently interspersed and occupied most of the space in between the seminiferous tubule. Vacuolization of the peritubular tissue surrounding the seminiferous tubule were rarely observed. In T2 (Figure 3), testes of the animals showed evidence of intact lumen, there was active spermatogenesis marked by the characteristic layered arrangement of cells from the germinal epithelium to the lumen. There was vacuolization of the peritubular tissue surrounding seminiferous tubule. The interstitial cells of Leydig were interspersed between the seminiferous tubule. Few spermatogenic cells were ob- 


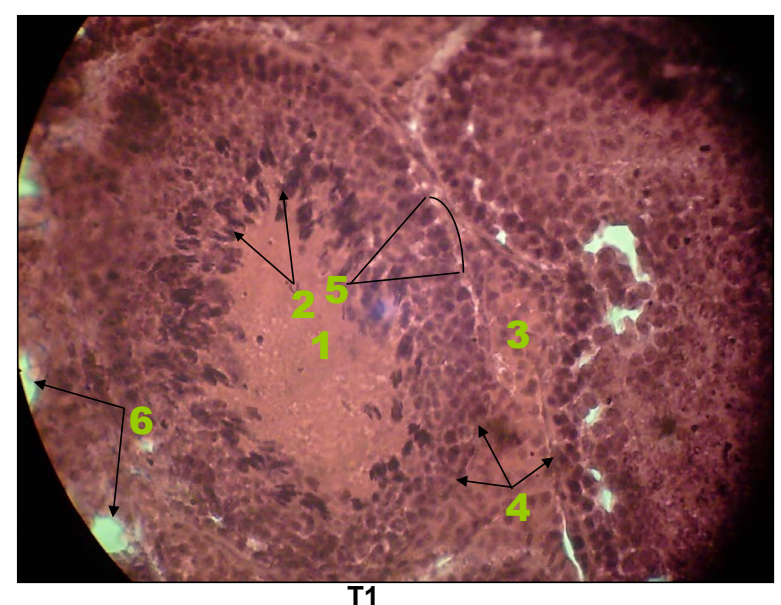

1: Lumen of seminiferous tubules; 2: Spermatids; 3: Leydig cells; 4: Myofibroblasts/peritubular tissue; 5: Germinal epithelium; 6: Vacuolization of myofibroblast. Magnification: $600 \times$ ( $\mathrm{H} \& \mathrm{E}$ stains).

Figure 2. Cross section of the seminiferous tubules of pig fed $0 \%$ microbially fermented cassava peel-based diet (T1).

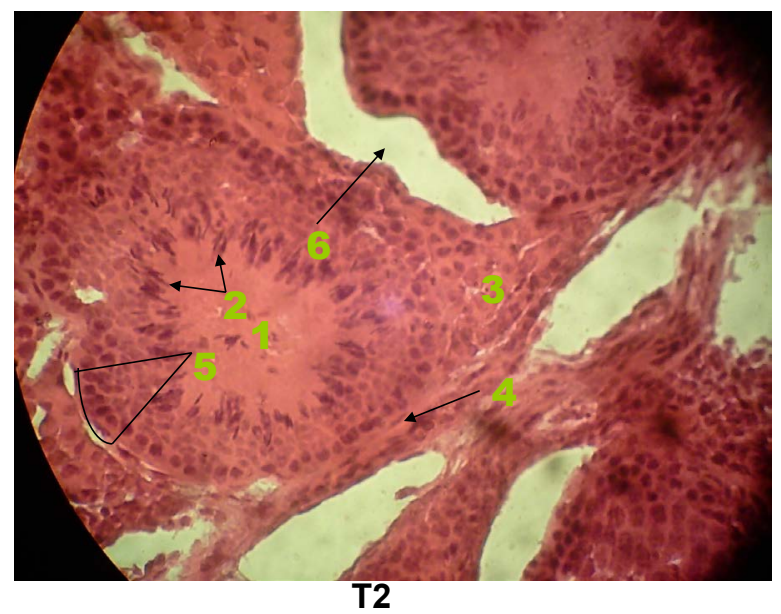

1: Lumen of seminiferous tubules; 2: Spermatids; 3: Leydig cells; 4: Myofibroblasts/peritubular tissue; 5: Germinal epithelium; 6: Vacuolization of myofibroblast Magnification: $600 \times$ (H \& E stains).

Figure 3. Cross section of the seminiferous tubules of pig fed $20 \%$ microbially fermented cassava peel-based diet (T2).

served compared with testis of animals on T1. In T3 (Figure 4), the testes of animals had intact lumen. The spermatogenic cells were at different stages of cell differentiation. Vacuolization were also observed within and between the seminiferous tubule. There was much keratinization of the myofibrils while the Leydig cells were much displaced and disrupted because of vacuolization.

In T4 (Figure 5), the animals' testis showed evidence of massive vacuolization, disruption and degeneration of the seminiferous tubule and primordial germ cells. No distinct lumen and Sertoli cells were visible. There was sloughing of apical seminiferous tubule epithelium into the lumen. There was disruption of peritubular cells while the interstitial cells of Leydig were totally shrunken.

These Histological examinations revealed progressive changes in testicular architecture according to treatment effects (Figures 2-5). This disruption and degeneration of the testicular tissues could be attributed to the toxic effect of residual cyanide $(16.75 \mathrm{mg} / \mathrm{kg}$ ) on the testes at $60 \%$ level of inclusion. This was similar to the alteration observed in spermatogenesis due to inclusion of gossypol [24], Tryotergium walfordii [25] and Achillea millefolium [26] in mice diet which were considered to be anti-spermatogenic agents. 


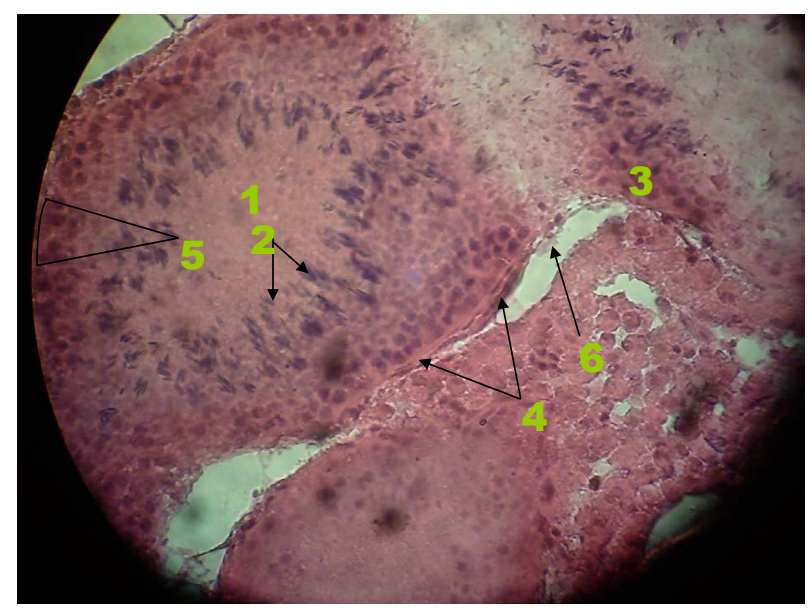

T3

1: Lumen of seminiferous tubules; 2: Spermatids; 3: Leydig cells; 4: Myofibroblasts/peritubular tissue; 5: Germinal epithelium; 6: Vacuolization of myofibroblast. Magnification: $600 \times$ ( $\mathrm{H} \& \mathrm{E}$ stains).

Figure 4. Cross section of the seminiferous tubules of pig fed $40 \%$ microbially fermented cassava peel-based diet (T3).

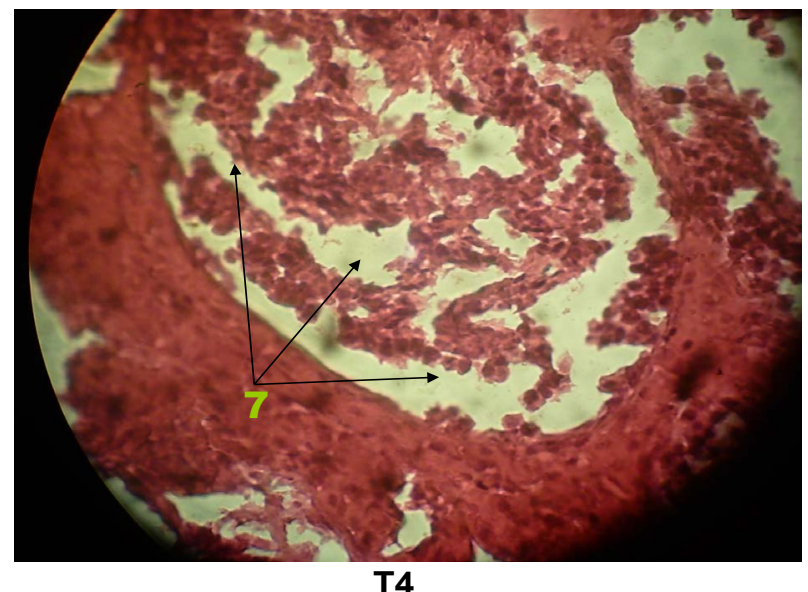

7: Vacuolization of the whole seminiferous tubule. Magnification: $600 \times(\mathrm{H}$ \& E stains)

Figure 5. Cross section of the seminiferous tubules of pig fed $60 \%$ microbially fermented cassava peel-based diet (T4).

The sloughing of apical seminiferous tubule epithelium into the lumen observed in the testis of animals fed T4 (Figure 5) could be have occurred when germ cell-to-Sertoli cell adhesion are lost as reported by Creasy [27]. The loss of germ and Sertoli cells confirmed the inhibitory effect of residual cyanide in MFCP $(16.75 \mathrm{mg} / \mathrm{kg})$ at $60 \%$ level of inclusion on spermatogenesis since Sertoli and germ cell adhesion are essential for successful spermatogenesis in animals [28].

Vacuolization and keratinization of seminiferous tubule and peritubular tissue of the seminiferous tubules were increased in the testes of animal fed MFCP diets. The vacuolization of the seminiferous tubule may be as a result of toxigenic nature of residual cyanide in MFCP that could probably engender reduced fertility. This is similar to the vacuolization and degeneration of seminiferous tubule observed in rat due to obstruction or dysfunction of epididymis [29] [30] causing abnormal fluid reabsorption.

The interstitial cells of Leydig were prominently interspersed in testes of animals fed diet T1 (Figure 2), sparsely interspersed in T2 (Figure 3), massively displaced and disrupted in T3 (Figure 4), and totally lost in T4 (Figure 5). It has been reported that Leydig cells secrete testosterone [31], and rostenedione and dihydroandros- 
terone when stimulated by pituitary luteinizing hormone. Kukucka and Misra [32] also reported that Leydig cells synthesize testicular oxytocin de novo and vitamin $C$ endogenously in rat and guinea pig. Thus, the harmful effect of residual cyanide in MFCP could be advanced for decrease in distribution of Leydig cells in testes animals fed diets T2 (Figure 3) and T3 (Figure 4) to loss in T4 (Figure 5). This may result in decrease in testosterone and oxytocin secretion thereby affecting effective libido and total sperm production in the animals.

\section{Conclusions}

The performance of the grower pigs was better in terms of total weight gained of the pigs in favour of the $40 \%$ level of inclusion of MFCP. This means that the inclusion of MFCP at $40 \%$ level in the diets of grower pigs will not adversely affect growth performance and the digestive physiology of the pigs. The result however reveals that nutrient and water absorption in the GIT are affected by dietary inclusion of microbially fermented cassava peel. These performance indicators of the normal gastro-intestinal physiology were decreased at $60 \%$ inclusion level of MFCP. Feeding pigs with inclusion of MFCP above $40 \%$ could therefore adversely affect the rate of nutrient absorption, gut health and general health status of growing pigs. Therefore, within the limit of this study MFCP should not be fed above $40 \%$ to growing pigs. Also, feeding boars with more than $40 \%$ inclusion MFCP could depress reproductive performance. The high relative weight of the prostate glands in pigs fed on the MFCP diets calls for more empirical evaluation, as it is suggestive of a pathological condition in the similitude of an abnormal enlargement of the gland in response to the diets. Hence, predisposition to prostate cancer could result from prolonged exposure to diets containing more than $40 \%$ MFCP as observed in this study. The testicular architecture observed in this study showed that feeding microbially fermented cassava peel higher than $40 \%$ inclusion in diet would lead to reduction in reproductive performance of growing pigs.

The prospects of value addition to cassava peels through the intervention of micro-organisms within the limit of this experiment are in the areas of better growth performance and feed conversion up to $40 \%$ inclusion level. The challenges or constraints are lowered reproductive performance and reduced growth rate that are experienced at levels of inclusion higher than $40 \%$, probably due to the crude fibre and residual cyanide levels in the microbially fermented peels. The focus of further research in this field should therefore be directed at those micro-organisms with better crude fibre and cyanide degrading ability than the ones used in this trial. However, from this experiment, tolerant levels of $0.35 \mathrm{mg}$ of $\mathrm{HCN}$ intake $/ \mathrm{kg}$ body weight, $11.16 \mathrm{mg}$ of HCN$/ \mathrm{kg}$ of feed and crude fibre level of $17.87 \%$ were established for growing pigs fed dietary inclusion of cassava peels fermented with a consortium of Lactobacillus coryneformis, Lactobacillus delbrueckii and Aspergillus fumigatus.

\section{Acknowledgements}

The authors express their gratitude to the Federal University of Technology, Akure under the Centre of Excellence for Food Security, for providing financial support for this research work.

\section{References}

[1] Otte, J. and Roland-Holst, D. (2007) Industrial Livestock Production and Global Health Risks. A Living from Livestock. Research Report. 1. RR Nr 07-09. Pharmacology, 42, 539-551.

[2] Osaro, O.M. (1995) Enhancing Production Performance of Smallholder Pig Farmers. Pig Production Workshop Training Manual, Zaria, 100-130.

[3] Ikani, I.E. and Dafwang, I.I. (1995) Pig Production Technology for Piggery Farmers. Extension Bulletin No. 25, Livestock Series No. 1, NAERLS, ABU Zaria, Nigeria.

[4] Sastry, N.S.R. and Thomas, C.K. (1976) Farm Animal Management. Vikkas Pub. House PVT. Ltd., 181.

[5] Aro, S.O. (2010) Growth and Reproductive Response of Swine Fed Fermented Cassava Tuber Wastes. Ph.D. Thesis, University of Ibadan, Ibadan, 1-176.

[6] Makkar, H.P.S. (1993) Anti-nutrient Factors in Food for Livestock. British Society for Animal Production, 16, 69-85.

[7] Israelides, C.J., Smith, A., Harhill, J.E., Bambalor, G. and Scallon, B. (1998) Pullulan Content of the Ethanol Precipitated from Agro-Industrial Wastes. Applied Microbiology and Biotechnology, 49, 613-617. http://dx.doi.org/10.1007/s002530051222

[8] Bi, Y. and Peter, W.S.C. (1996) Effect of Crude Fibre Level in the Diet on the Intestinal Morphology of Growing Rabbits. Laboratory Animal, 30, 143-148. http://dx.doi.org/10.1258/002367796780865826 
[9] Nhassico, D., Muquigue, H., Cliff, J., Cumbana, A. and Bradbury, J.H. (2008) Rising African Cassava Production, Diseases Due to High Cyanide Intake and Control Measures. Journal of the Science of Food and Agriculture, 88, 20432049. http://dx.doi.org/10.1002/jsfa.3337

[10] Jorgensen, H., Zhao, X.Q., Bach Knudsen, K.E. and Eggum, B.O. (1996) The Influence of Dietary Fibre Source and Level on the Development of Gastrointestinal Tract, Digestibility and Energy Metabolism in Broiler Chickens. British Journal of Nutrition, 75, 379-395. http://dx.doi.org/10.1079/BJN19960141

[11] Darcy, B. (1982) Transit et Digestion dans L'intestin Grêle Chez le Porc. In: Laplace, J.P., Corring, T. and Rérat, A., Eds., Proceedings of International Seminar on Digestive Physiology of Pig, Les Colloques de 1' INRA No. 12, Paris, 45-59.

[12] Wenk, C. (2001) The Role of Dietary Fibre in the Digestive Physiology of the Pig. Animal Feed Science and Technology, 90, 21-33. http://dx.doi.org/10.1016/S0377-8401(01)00194-8

[13] Asp, N.G. (1996) Dietary Carbohydrates: Classification by Chemistry and Physiology. Food Chemistry, 57, 9-14. http://dx.doi.org/10.1016/0308-8146(96)00055-6

[14] Varel, V.H. and Yen, J.T. (1997) Microbial Perspective on Fibre Utilisation by Swine. Journal of Animal Science, 75, 2715-2722.

[15] Bindelle, J. (2005) A Rapid Estimation of Nitrogen Bound to Neutral Detergent Fibre in Forages by Near Infrared Reflectance Spectroscopy. Proceedings of the XXth International Grassland Congress, University College Dublin, 259.

[16] Cummings, J.H. and Englyst, H.N. (1995) Gastro-Intestinal Effects of Food Carbohydrate. American Journal of Clinical Nutrition, 61, S928-S945.

[17] Sauer, W.C., Mosenthin, R., Ahrens, F. and Den Hartog, L.A. (1991) The Effect of Source of Fiber on Ileac and Fecal Amino Acid Digestibility and Bacterial Nitrogen Excretion in Growing Pigs. Journal of Animal Science, 69, 40704077.

[18] Leterme, P. (2005) Chemical Composition, Nutritive Value and Voluntary Intake of Tropical Tree Foliage and Cocoyam in Pigs. Journal of the Science of Food and Agriculture, 85, 1725-1732. http://dx.doi.org/10.1002/jsfa.2177

[19] Spiller, G., Margo, N.W., Sherwood, L. and Gorbach, A. (2001) Influence of Fibre on the Ecology of the Intestinal Flora. CRC Press, Boca Raton, $257 \mathrm{p}$.

[20] Drummond, K. and Lisa, M. (2007) Nutrition for Food Service and Culinary Professionals. John Wiley and Sons, Hoboken, $114 \mathrm{p}$.

[21] Eliasson, R. and Lindholmer, C. (1976) Functions of Male Accessory Genital Organs. In: Hafez, E.S.E., Ed., Human Semen and Fertility Regulation in Man, Mosby Co., St. Louis, 44-50.

[22] Green, C.M., Cockle, S.M. and Watson, P.F. (1996) Fertilization Promoting Peptide, a Tripeptide Similar to Thyrotrophin-Releasing Hormone, Stimulates the Capacitation and Fertilizing Ability of Human Spermatozoa in Vitro. Human Reproduction, 11, 830-836. http://dx.doi.org/10.1093/oxfordjournals.humrep.a019262

[23] Egbunike, G.N., Dawodu, M.O. and Eboreime, A.O.A. (1999) Effect of Gossypol Acetic Acid on Sperm Production and Fertility in the Rat. Tropical Animal Production Investigation, 2, 111-117.

[24] Haider, S.G., Passial, D. and Chen, K. (1985) Reversible Changes in Rat Spermatogenesis Induced by an Antifertility Substance (Gossypol): A Histochemical Report. Acta Histochemica, 77, 185-191, IN3-IN4. http://dx.doi.org/10.1016/S0065-1281(85)80081-7

[25] Qian, S.Z., Zhong, C.Q. and Xu, Y. (1986) Effect of Trypterygium wilfordii on The Fertility of Rats. Contraception, 33, 105-110. http://dx.doi.org/10.1016/0010-7824(86)90076-4

[26] Montanari, T., De Carvalho, J.E. and Dolder, H. (1998) Antispermatogenic Effect of Achillea millefolium L. in Mice. Contraception, 58, 309-313. http://dx.doi.org/10.1016/S0010-7824(98)00107-3

[27] Creasy, D.M. (2002) Histopathology of the Male Reproductive System II-Evaluation. In: Chapin, R.E. and Boekelheide, K., Eds., Chapter 16, Unit 16.4, John Willy and Sons, Inc., New York.

[28] Rodriguez, I., Ody, C., Araki, K., Garcia, I. and Vassalli, P. (1997) An Early and Massive Wave of Germinal Cell Apoptosis Is Required for the Development of Functional Spermatogenesis. The EMBO Journal, 16, 2262-2270. http://dx.doi.org/10.1093/emboj/16.9.2262

[29] Altay, B., Hekimgil, M., Kefi, A. and Cikili, N. (2001) Histopathological Examination of both Ipsilateral and Contralateral Testes with Different Obstructive Models in Prepubertal and Adult Rats. BJU International, 88, 84-89. http://dx.doi.org/10.1046/j.1464-410x.2001.02256.x

[30] Flickinger, C.J., Baran, M.L., Howards, S.S. and Herr, J.C. (1999) Degeneration of the Seminiferous Epithelium Following Epididymal Obstruction in Prepubertal Rats. Anatomical Record, 254, 76-86.

[31] Cook, J.C., Kiinefeiter, G.R., Hardisty, J.F., Sharpe, R.M. and Foster, P.M. (1999) Rodent Leydig Cells Tumorigenesis: 
A Review of the Pathology, Physiology, Mechanism and Relevance to Humans. Critical Reviews in Toxicology, 29, 169-261. http://dx.doi.org/10.1080/10408449991349203

[32] Kukucka, M.A. and Misra, H.P. (1992) HPLC Determination of an Oxytocin-Like Peptide Produced by Isolated Guinea Pig Leydig Cells: Stimulation by Ascorbate. Systems Biology in Reproductive Medicine, 29, 185-190.

http://dx.doi.org/10.3109/01485019208987723 
Scientific Research Publishing (SCIRP) is one of the largest Open Access journal publishers. It is currently publishing more than 200 open access, online, peer-reviewed journals covering a wide range of academic disciplines. SCIRP serves the worldwide academic communities and contributes to the progress and application of science with its publication.

Other selected journals from SCIRP are listed as below. Submit your manuscript to us via either submit@scirp.org or Online Submission Portal.
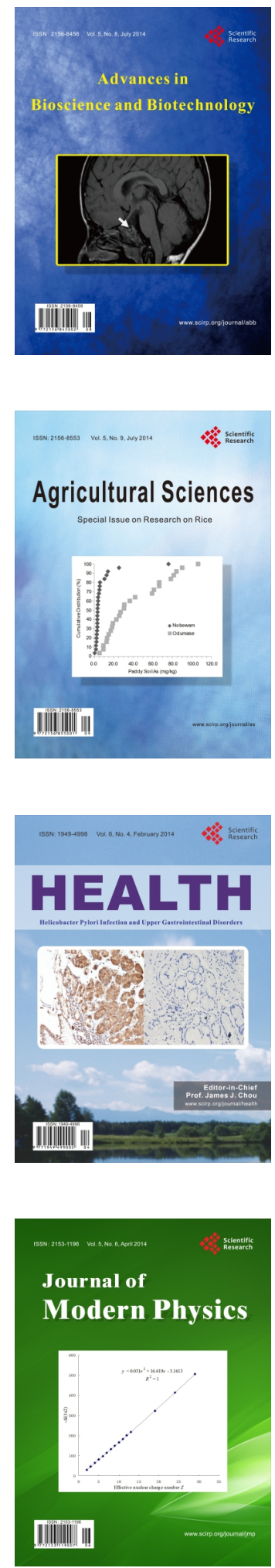
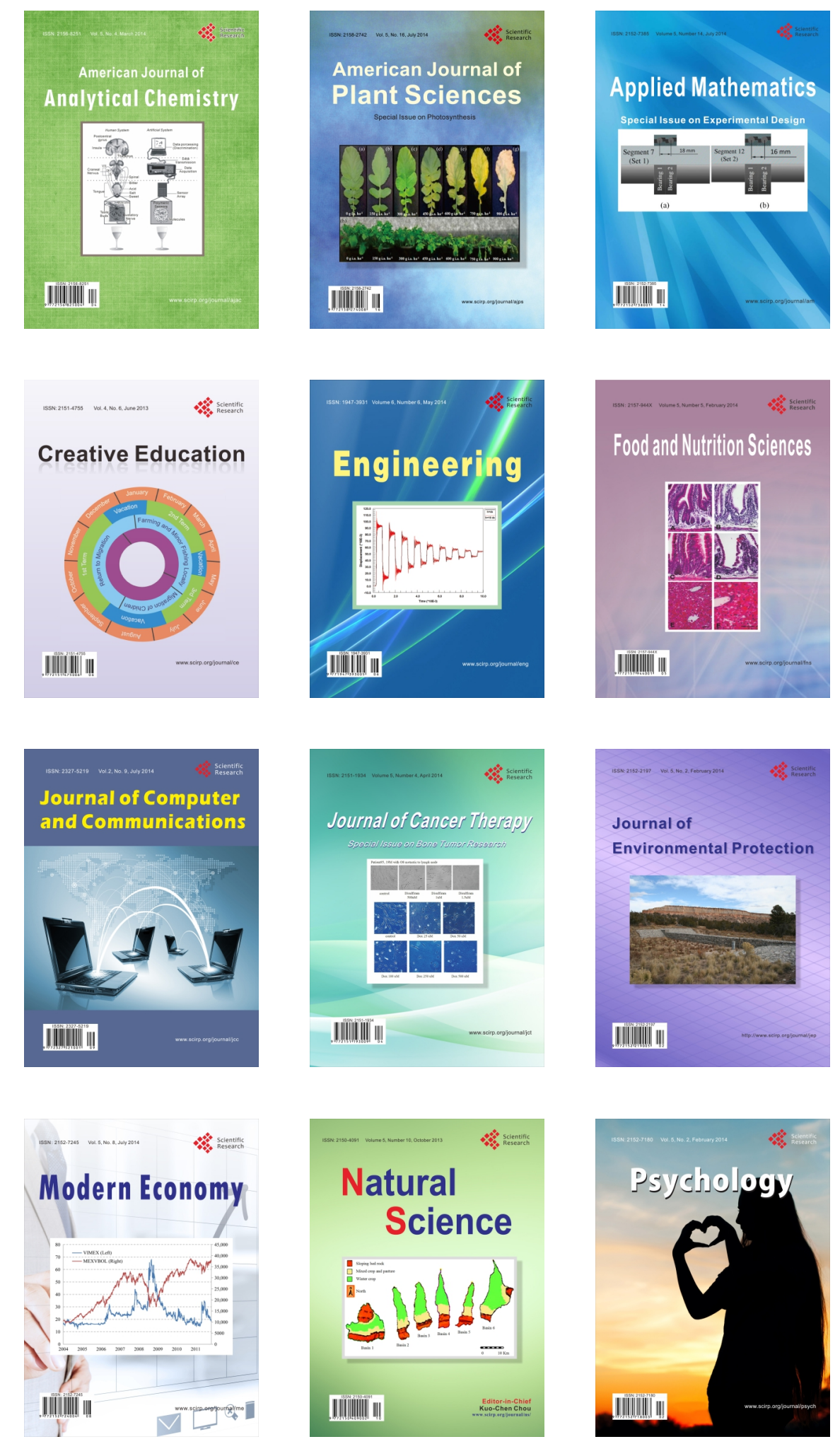